\title{
SULFENTRAZONE PHYTOREMEDIATION UNDER FIELD CONDITIONS ${ }^{1}$
}

\author{
ALESSANDRA FERREIRA BELO ${ }^{2}$, FÁBIO RIBEIRO PIRES ${ }^{2 *}$, ROBSON BONOMO ${ }^{2}$, ALBERTO CARGNELUTTI \\ FILHO $^{3}$, LUIS HENRIQUE ORTELAN TENIS ${ }^{2}$
}

\begin{abstract}
Phytoremediation is a technique that has been used with increasing frequency to decontaminate soils treated with herbicides that have long-term residual effects, such as sulfentrazone. The goal was to assess phytoremediation of the herbicide sulfentrazone under field conditions by the species Canavalia ensiformis and Crotalaria juncea. The treatments consisted of combinations of the plant species C. ensiformis and C. juncea plus a control treatment (with manual weeding) and four doses of the herbicide sulfentrazone. The experimental design used herein was a split-plot randomized block design with four replicates per subplot. The treatments were kept in the field for 75 days. After this period, the experimental area was again furrowed and fertilized, considering the requirements for Pennisetum glaucum, a plant used as an indicator of the presence of sulfentrazone. Thirty-four days after sowing pearl millet, the fresh and dry shoot masses of the plants were assessed. At the end of the cycle, the plant height, stem diameter, internode length, number of leaves, number of panicles, and fresh and dry panicle masses were determined. Previous cultivation of phytoremediation species $C$. ensiformis and $C$. juncea promotes sulfentrazone remediation. $C$. ensiformis is the most efficient species for the decontamination of the herbicide sulfentrazone under field conditions.
\end{abstract}

Keywords: Green manure. Canavalia ensiformis. Crotalaria juncea. Soil decontamination. Crop succession.

\section{FITORREMEDIAÇÃO DE SULFENTRAZONE EM CONDIÇÕES DE CAMPO}

RESUMO - A fitorremediação é uma técnica que vem sendo utilizada na descontaminação de solos tratados com herbicidas de longo efeito residual devido à sua eficiência na descontaminação. Objetivou-se avaliar a fitorremediação do herbicida sulfentrazone em campo, pelas espécies Canavalia ensiformis e Crotalaria juncea. Os tratamentos foram compostos pela combinação entre as espécies vegetais $C$. ensiformis e $C$. juncea, mais um tratamento controle (com capina manual) e quatro doses do herbicida sulfentrazone. $\mathrm{O}$ delineamento experimental foi blocos casualizados com parcelas subdivididas, com quatro repetições. As espécies fitorremediadoras foram mantidas no campo por 75 dias. Neste mesmo período, foi mantido o tratamento controle. Após esse período, a área experimental foi novamente sulcada e fertilizada considerando as necessidades do Pennisetum glaucum, planta utilizada como indicadora da presença de sulfentrazone. Aos 34 dias após a semeadura do P. glaucum, avaliaram-se a massa fresca e seca da parte aérea. Ao final do ciclo, determinaram-se altura, diâmetro do colmo, comprimento do entre nó, número de folhas, número de panículas, massa fresca e seca da panícula. O cultivo prévio das espécies fitorremediadoras $C$. ensiformis e $C$. juncea promove a remediação do sulfentrazone. C. ensiformis é a espécie mais eficiente na descontaminação do herbicida sulfentrazone a campo.

Palavras-chave: Adubos verdes. Canavalia ensiformis. Crotalaria juncea. Descontaminação do solo. Sucessão de culturas.

\footnotetext{
*Corresponding Author

${ }^{1}$ Received for publication in $05 / 15 / 2015$; accepted in $12 / 21 / 2015$.

Part of postdoctoral work of the first author.

${ }^{2}$ Biological and Agricultural Science Department, Universidade Federal do Espírito Santos, São Mateus, ES, Brazil; ferreiragro@yahoo.com.br, pires.fr@gmail.com, robson.bonomo@gmail.com, luluis12@hotmail.com.

${ }^{3}$ Center of Rural Science, Universidade Federal de Santa Maria, Santa Maria, RS, Brazil; cargnelutti@pq.cnpq.br.
} 


\section{INTRODUCTION}

Brazil is one of the few major agricultural producers that compete to supply the global demand for food, fiber, and renewable energy. This demand for productivity is met in part by the use of agrochemicals in the field (TAVELLA et al., 2011).

Herbicides are the most widely used crop protection products in the world and are essential for the large-scale production of food. They are compounds synthesized for their action against toxic plants, but they can have negative effects on various other organisms (SANTOS et al., 2013a).

Concern regarding the prevention or remediation of the negative effects of herbicides in the various environmental compartments has increased over the years, and is in alignment with the new view of production, in which increasing productivity is no longer the only goal; producers also aim to maintain a high production level over time. In this context, the development of techniques for the remediation of areas contaminated with herbicides has been gaining attention in several countries across the world, especially in Brazil.

The herbicide sulfentrazone has high soil persistence and leaching potential (PARAÍBA et al., 2003), mainly due to its low affinity for organic matter. When applied to soybean crops, it showed great persistence in soil, significantly affecting the development of millet and oat crops in succession (BLANCO; VELINI, 2005). Given the above, attention should be paid to the persistence of sulfentrazone in the soil; it can cause toxicity to sensitive crops grown in succession and also to soil microorganisms. In addition, there is the possibility of contamination of groundwater due to its high potential for leaching.

In an attempt to identify ways to work around and/or reduce this problem, greater emphasis has been given in recent years to the study of phytoremediation. This consists of procedures involving plants and their associated microbiota that remove or immobilize contaminants or render them harmless or less toxic to the ecosystem (ACCIOLY; SIQUEIRA, 2000).

Several studies have showed that the cultivation of certain plant species can decontaminate areas where xenobiotics, such as soilapplied herbicides, are present (ANDERSON et al., 1994; ANDERSON; COATS, 1995; PERKOVICH et al., 1996; WILSON et al., 2000; BELO et al., 2011; MONQUERO et al., 2013). In recent years, especially in Brazil, studies involving phytoremediation, in addition to its environmental relevance (MADALÃO et al., 2012; SANTOS et al., 2013b), have received great stimulus for use in agricultural areas.

Some studies have shown that it is possible to use plants to reduce the phytotoxicity of herbicides (the carryover effect) to susceptible crops grown in areas that have received such compounds (SANTOS et al., 2007; ASSIS et al., 2010; BELO et al., 2011; MADALÃO et al., 2012; MONQUERO et al., 2013). This reduction indicates that phytoremediation may shorten the time required before an area becomes available for the cultivation of said species (NASCIMENTO et al., 2015), which can lead to greater optimization of land use, with greater economic returns for agricultural activity.

Studies of phytoremediation involving the herbicide sulfentrazone have started to draw attention. In a bioassay conducted by Belo et al. (2011) using sorghum as an indicator plant, Helianthus annuus was the highest performer in reducing carryover effects. In turn, Madalão et al. (2013) selected the green manure Canavalia ensiformis, Crotalaria juncea and Dolichos lablab as having potential for phytoremediation. Such results show the environmental viability of applying phytoremediation to sulfentrazone-contaminated soils. However, further investigation with these species under field conditions is required because all of the available preliminary results were obtained under controlled conditions.

The goal of this study was to assess the phytoremediation of the herbicide sulfentrazone in the field by the species $C$. ensiformis and $C$. juncea.

\section{MATERIAL AND METHODS}

The experiment was established under field conditions in an experimental area without herbicide application history, located on the campus of the North of Espírito Santo University Centre, belonging to the Federal University of Espírito Santo (Universidade Federal do Espírito Santo - UFES), in the municipality of São Mateus - ES. The soil in this area is classified as an abruptic dystrophic Yellow Argisol (Ultisol), for which the chemical and texture characterization are given in Table 1. The experiment was conducted from December 2012 to July 2013.

The experimental design used herein was a split-plot randomized block design, in which the main plot factor was the herbicide dose and the subplot factor was the plant species, with four replicates. Treatments consisted of the combination of the plant species $C$. ensiformis (jack bean) and Crotalaria juncea (sunn hemp), in addition to a control treatment (with manual weeding), and four doses of the herbicide sulfentrazone $(0,200,400$ and $800 \mathrm{~g} \mathrm{ha}^{-1}$ a.i.). These doses correspond to zero, one quarter, one half and one times the recommended dose for the culture of sugarcane when weeds are present between plants in the area of the Cyperus rotundus (nutsedge). Each subplot was $8 \mathrm{~m} \times 3 \mathrm{~m}$, totaling an area of $24 \mathrm{~m}^{2}$. 
Table 1. Chemical composition and texture of the ploughable layer $(0.0-0.20 \mathrm{~m})$ of the soil used in the experiment ${ }^{(1)}$

\begin{tabular}{|c|c|c|c|c|c|c|c|c|c|}
\hline \multicolumn{10}{|c|}{ Particle size analysis $\mathrm{g} \mathrm{kg}^{-1}$} \\
\hline \multicolumn{2}{|c|}{ Clay } & \multicolumn{2}{|r|}{ Silt } & & \multicolumn{2}{|c|}{ Sand } & \multicolumn{3}{|c|}{ Texture classification } \\
\hline \multicolumn{2}{|c|}{29} & \multicolumn{2}{|r|}{02} & & \multicolumn{2}{|c|}{69} & \multicolumn{3}{|c|}{ sandy clay loam } \\
\hline \multicolumn{10}{|c|}{ Chemical analysis } \\
\hline $\mathrm{pH}$ & $\mathrm{P}$ & $\mathrm{K}^{+}$ & $\mathrm{Ca}^{2+}$ & $\mathrm{Mg}^{2+}$ & $\mathrm{H}+\mathrm{Al}$ & $\mathrm{Al}^{3+}$ & $\operatorname{CTC}(\mathrm{t})$ & V & MO \\
\hline $\mathrm{H}_{2} \mathrm{O}$ & \multicolumn{2}{|c|}{$----m g \mathrm{dm}^{-3}----$} & \multicolumn{5}{|c|}{ - } & $\%$ & dag $\mathrm{kg}^{-1}$ \\
\hline 5.9 & 1.0 & 34.0 & 1.8 & 0.9 & 1.8 & 0.2 & 3.0 & 61.2 & 0.3 \\
\hline
\end{tabular}

The nomenclature and chemical structure of sulfentrazone, according Rodrigues and Almeida (2011), is 2',4'-dichloro-5-(4-difluoromethyl-4,5dihydro-3-methyl-5-oxo-1H-1,2,4-triazol-1-yl) methanesulfonanilide, with the trade name Boral 500 SC.

Before sowing, the soil underwent conventional tillage, i.e., one ploughing and two harrowings. Next, the herbicide sulfentrazone was applied using a $\mathrm{CO}_{2}$-pressurised knapsack sprayer coupled to a bar with six TT 110.02 spray nozzles, applying a spray volume of $200 \mathrm{~L} \mathrm{ha}^{-1}$. Ten days after application, the area was furrowed and fertilized with $500 \mathrm{~kg} \mathrm{ha}^{-1}$ of 4-14-8 fertilizer. The next day, the phytoremediation species $C$. ensiformis and $C$. juncea were manually sowed. The plants were spaced $0.45 \mathrm{~m}$ apart, and the plant population was 20 plants $\mathrm{m}^{-2}$ for $C$. ensiformis and 120 plants $\mathrm{m}^{-2}$ for $C$. juncea, which are the values most recommended to promote phytoremediation of sulfentrazonecontaminated soil (FERRAÇO, 2012). During the experimental period, the soil moisture contents were kept at the desired levels using the daily water balance method.

The phytoremediation species were kept for 75 days after sowing (DAS) in the field, in the full flowering stage, at which time the plants were reaped near the ground. Meanwhile, the control treatment was kept free of weed plants by manual weeding. While managing the phytoremediation species, soil samples were collected for chemical analysis to assess the need for new fertilization of the area for later planting of the species used to indicate the presence of sulfentrazone residues in the soil (pearl millet - Pennisetum glaucum var. ADR 8010).

After two weeks, the experimental area was again furrowed and fertilized using $31.5 \mathrm{~g} \mathrm{~m}^{-1}$ of 414-8 fertilizer, and pearl millet was immediately sowed. The plants were spaced $0.45 \mathrm{~m}$ apart, and 32 seeds $\mathrm{m}^{-1}$ were manually sowed. During the whole experiment, the area of all plots was kept free from weed plants by manual weeding.

At 34 DAS of the pearl millet, $50-\mathrm{cm}$ lines were marked inside the useful area of each subplot with the aid of a measuring tape, and plants were harvested at a height of $5 \mathrm{~cm}$ from the ground to assess the shoot fresh and dry matter. For this purpose, the plant material was placed in a forced-air oven $\left(70 \pm 2{ }^{\circ} \mathrm{C}\right)$ for $72 \mathrm{~h}$ and weighed on an analytical scale. At 84 DAS (end of cycle), 2-m lines were marked inside the useful area of each subplot with the aid of a measuring tape, and plants were harvested at a height of $5 \mathrm{~cm}$ from the ground to assess the following parameters: plant height, using a ruler and using the apical meristem as a reference; stem diameter; internode length; number of leaves; number of panicles; fresh and dry panicle mass; and shoot dry mass of the pearl millet plants.

After collection and tabulation of data, analysis of variance was performed. Significant phytoremediation effects of the species within each dose of herbicide were analyzed using Tukey's test at a significance level of 0.05 , and the significant effects of each sulfentrazone dose on each phytoremediation species were determined by regression analysis, in which the equation coefficients were tested using a t-test at a significance level of 0.05 . However, no model equation provided a good fit for any of the variables that was consistent with the biological behavior we observed.

\section{RESULTS AND DISCUSSION}

The fresh and dry masses of $P$. glaucum, analyzed 34 days after sowing, were influenced by the different soil management systems we assessed. Greater production of $P$. glaucum fresh mass was obtained when the plants were cultivated in soil that had previously been cultivated with C. juncea and $C$. ensiformis (Table 2). The production of dry mass was greatest when $P$. glaucum was cultivated in soil that had previously been cultivated with $C$. ensiformis. These results show that $C$. ensiformis and $C$. juncea possess the ability to remediate soils contaminated with sulfentrazone. In addition, these phytoremediator species may be contributing to the fixation of atmospheric nitrogen and adding carbon to the soil, which is essential to increase productivity, thereby contributing to the sustainability of agricultural systems. The constant supply of organic material through the use of green manure ensures the maintenance of organic matter quality and hence, soil carbon and nitrogen stocks (RIBEIRO et al., 2011; WIESMEIER et al., 2015). 
Table 2. Fresh and dry mass of Pennisetum glaucum cultivated under different management systems in soil contaminated with the herbicide sulfentrazone, at 34 days after sowing.

\begin{tabular}{|c|c|c|c|c|}
\hline \multirow{3}{*}{$\operatorname{DOSE}\left(\mathrm{g} \mathrm{ha}^{-1}\right.$ a.i. $)$} & \multicolumn{3}{|c|}{ Fresh matter $^{(1)}(\mathrm{g})$} & \multirow[b]{3}{*}{ Mean } \\
\hline & \multicolumn{3}{|c|}{ Management } & \\
\hline & Manual weeding & Crotalaria juncea & Canavalia ensiformis & \\
\hline 0 & 121.99 & 165.24 & 217.00 & 168.08 \\
\hline 200 & 112.43 & 140.64 & 201.19 & 151.42 \\
\hline 400 & 104.34 & 236.10 & 208.86 & 183.10 \\
\hline 800 & 134.17 & 188.43 & 232.34 & 184.98 \\
\hline Mean & $118.23 \mathrm{~b}$ & $182.60 \mathrm{a}$ & $214.85 \mathrm{a}$ & 171.89 \\
\hline CV (\%) & & 22.71 & & \\
\hline \multirow{2}{*}{$\operatorname{DOSE}\left(\mathrm{g} \mathrm{ha}^{-1}\right.$ a.i. $)$} & \multicolumn{3}{|c|}{ Dry matter $^{(1)}(\mathrm{g})$} & \\
\hline & Manual weeding & Crotalaria juncea & Canavalia ensiformis & Mean \\
\hline 0 & 12.11 & 16.69 & 23.21 & 17.34 \\
\hline 200 & 11.50 & 15.24 & 21.06 & 15.93 \\
\hline 400 & 10.54 & 22.20 & 21.46 & 18.06 \\
\hline 800 & 13.04 & 18.59 & 23.89 & 18.51 \\
\hline Mean & $11.80 \mathrm{c}$ & $18.18 \mathrm{~b}$ & $22.40 \mathrm{a}$ & 17.46 \\
\hline $\mathrm{CV}(\%)$ & & 20.20 & & \\
\hline
\end{tabular}

${ }^{(1)}$ Means that are not followed by the same lower-case letter in rows differ based on Tukey's test at a significance level of 0.05 .

Madalão et al. (2012) observed an increase in biomass production when $C$. juncea had been cultivated prior to $P$. glaucum, allowing $P$. glaucum to develop in a previously sulfentrazonecontaminated soil. Smaller reductions in fresh and dry mass were achieved in soil dosed with sulfentrazone up to a $400 \mathrm{~g} \mathrm{ha}^{-1}$ a.i., $200 \mathrm{~g} \mathrm{ha}^{-1}$ a.i., respectively, compared with non-remediated soil.

One of the few studies of herbicide phytoremediation in the field was conducted by Procópio et al. (2007). In that study, the plant height, shoot dry mass and bean grain yield of indicator plants cultivated in an area previously contaminated with trifloxysulfuron-sodium were higher at any of the tested contamination levels when there had been a previous cultivation of sunn hemp or jack bean (phytoremediation species). At the lowest level of herbicide contamination, jack bean cultivation was more efficient than that of sunn hemp at mitigating the deleterious effects of trifloxysulfuron-sodium on bean grain yield.

The $P$. glaucum plants cultivated on soil free from sulfentrazone contamination and with previous cultivation of $C$. juncea and $C$. ensiformis achieved greater height (Table 3). Facing this result, the possibility of allelopathic effects due to previous cultivation of phytoremediation species can be discarded. A similar result was obtained by Procópio et al. (2007), who did not observe deleterious allelopathic effects of phytoremediation legumes (jack bean and sunn hemp) on the common bean when the species were cultivated in succession, based on plant height assessments.

When soil was contaminated with sulfentrazone (400 and $800 \mathrm{~g} \mathrm{ha}^{-1}$ a.i.) and subsequently remediated with $C$. juncea and $C$. ensiformis, $P$. glaucum achieved greater height than with weeding alone (Table 3 ). These results confirm the capacity of $C$. juncea and $C$. ensiformis to remedy soils contaminated with the herbicide sulfentrazone. In addition, these species may have contributed to improved soil fertility (CICEK et al., 2014), which may also have contributed to the increased growth rate of $P$. glaucum.

In a study by Alcantara et al. (2000), it was noted that the superior nutrient contribution of pigeon pea green manure compared with sunnhempjuncea was accounted for by higher dry matter production. It was also found that the use of green manure provides significant improvement in some chemical properties of soil.

$P$. glaucum plants displayed larger stem diameters when cultivated in soil that had been previously cultivated with $C$. ensiformis in comparison with weeding alone, regardless of the sulfentrazone dose assessed (Table 3). In a study conducted in a greenhouse, Madalão et al. (2012) selected $C$. juncea as the species that led to the best development of $P$. glaucum cultivated after phytoremediation, compared with the control without phytoremediation. These contrasting results regarding the phytoremediation capacity of $C$. ensiformis and $C$. juncea may have been due to the different environments in which the experiments were conducted, as Madalão et al. (2012) conducted their trials in the greenhouse and this work was carried out in the field.

In the weeding treatment, a shorter internode length was observed for P. glaucum in comparison with the treatments involving previous cultivation of C. juncea and C. ensiformis (Table 3). This difference demonstrates the importance of phytoremediation as a technique to decontaminate soils contaminated by herbicides with long-term residual periods in the soil, such as sulfentrazone. These results corroborate those obtained by Belo et al. (2011) using the species H. annuus, C. ensiformis, D. lablab, and Arachis hypogaea to decontaminate sulfentrazone-contaminated soil.

Regarding the number of leaves on $P$. 
glaucum plants, better results were observed in the treatments in which the soil had been previously cultivated with $C$. ensiformis than in the weedingonly treatment (Table 3 ). Once more, C. ensiformis stands out as a species appropriate for the phytoremediation of soils contaminated with sulfentrazone. This potential may be due to the fact that $C$. ensiformis releases exudates that stimulate their microbiota, which in turn contributes to the degradation of sulfentrazone. The cultivation of green manures for consecutive years may stimulate the action of microorganisms and improve soil quality (BUZINARO et al., 2009; FOUCAULT et al., 2013).

In addition to having the capacity to remediate soils contaminated with other herbicides, such as tebuthiuron (PIRES et al., 2005) and trifloxysulfuron-sodium (SANTOS et al., 2004; PROCÓPIO et al., 2005; BELO et al., 2007), C. ensiformis can be used as green manure (PIRES et al., 2006). It was also proven that the greatest evolution of $\mathrm{CO}_{2}$ occurs in the rhizosphere soil of $C$. ensiformis treated with tebuthiuron. This result reveals the essential contribution of this herbicide to the decontamination process (PIRES et al., 2005).

Table 3. Height $(\mathrm{cm})$, stem diameter $(\mathrm{cm})$, internode length $(\mathrm{cm})$, number of leaves and number of panicles for Pennisetum glaucum cultivated under different management systems of soil contaminated with the herbicide sulfentrazone, at 84 days after sowing.

\begin{tabular}{|c|c|c|c|c|}
\hline \multirow{3}{*}{$\operatorname{DOSE}\left(\mathrm{g} \mathrm{ha}^{-1}\right.$ a.i. $)$} & \multicolumn{3}{|c|}{ Management } & \multirow[b]{2}{*}{ Mean } \\
\hline & Manual weeding & Crotalaria juncea & Canavalia ensiformis & \\
\hline & \multicolumn{4}{|c|}{$\operatorname{Height}^{(1)}(\mathrm{cm})$} \\
\hline 0 & $105.93 \mathrm{~b}$ & $132.16 \mathrm{a}$ & $133.11 \mathrm{a}$ & 123.73 \\
\hline 200 & $110.18 \mathrm{ab}$ & $101.99 \mathrm{~b}$ & $118.25 \mathrm{a}$ & 110.14 \\
\hline 400 & $109.34 b$ & $135.12 \mathrm{a}$ & $127.33 \mathrm{a}$ & 123.93 \\
\hline 800 & $102.63 \mathrm{~b}$ & $117.83 \mathrm{a}$ & $127.69 \mathrm{a}$ & 116.05 \\
\hline Mean & 107.02 & 121.77 & 126.60 & 118.46 \\
\hline CV (\%) & & 7.02 & & \\
\hline $\operatorname{DOSE}\left(\mathrm{g} \mathrm{ha}^{-1}\right.$ a.i. $)$ & & Stem diameter ${ }^{(1)}(c$ & & \\
\hline 0 & 5.31 & 6.07 & 5.94 & 5.77 \\
\hline 200 & 5.53 & 5.60 & 6.29 & 5.81 \\
\hline 400 & 6.07 & 6.42 & 6.43 & 6.31 \\
\hline 800 & 5.29 & 5.92 & 5.99 & 5.73 \\
\hline Mean & $5.55 \mathrm{~b}$ & $6.00 \mathrm{ab}$ & $6.16 \mathrm{a}$ & 5.90 \\
\hline CV (\%) & & 9.89 & & \\
\hline $\operatorname{DOSE}\left(\mathrm{g} \mathrm{ha}^{-1}\right.$ a.i.) & & Internode length $^{(1)}$ & & \\
\hline 0 & 16.91 & 19.16 & 19.32 & 18.47 \\
\hline 200 & 15.98 & 18.14 & 18.21 & 17.44 \\
\hline 400 & 17.94 & 18.40 & 18.29 & 18.21 \\
\hline 800 & 16.99 & 17.52 & 17.07 & 17.19 \\
\hline Mean & $16.96 \mathrm{~b}$ & $18.30 \mathrm{a}$ & $18.22 \mathrm{a}$ & 17.83 \\
\hline CV (\%) & & 6.45 & & \\
\hline DOSE (g ha ${ }^{-1}$ a.i.) & & Number of leaves & & \\
\hline 0 & 188.75 & 221.75 & 284.50 & 231.67 \\
\hline 200 & 22575 & 200.00 & 246,25 & 224.00 \\
\hline 400 & 203.25 & 304.25 & 317.25 & 274.92 \\
\hline 800 & 210.75 & 233.00 & 253.25 & 232.33 \\
\hline Mean & $207.13 b$ & $239.75 \mathrm{ab}$ & $275.31 \mathrm{a}$ & 240.73 \\
\hline CV (\%) & & 22.19 & & \\
\hline $\operatorname{DOSE}$ (g ha ${ }^{-1}$ a.i.) & & Number of panicle & & \\
\hline 0 & 36.25 & 42.50 & 49.00 & 42.58 \\
\hline 200 & 47.00 & 36.25 & 41.00 & 41.42 \\
\hline 400 & 40.25 & 47.75 & 50.25 & 46.08 \\
\hline 800 & 29.50 & 39.75 & 45.25 & 38.17 \\
\hline Mean & $38.25 \mathrm{~b}$ & $41.56 \mathrm{ab}$ & $46.38 \mathrm{a}$ & 42.06 \\
\hline CV (\%) & & 19.49 & & \\
\hline
\end{tabular}

Regarding the number of $P$. glaucum panicles, this value was smaller when the plant was cultivated on soil that was kept clean, i.e., without previous cultivation of phytoremediation species ( $C$. juncea and $C$. ensiformis). The best results were obtained when the soil had been previously cultivated with $C$. ensiformis (Table 3). These results emphasize the potential of $C$. ensiformis to remedy sulfentrazonecontaminated soil, as well as the importance of previous cultivation with phytoremediator species in soil contaminated with this product in order to avoid interference from the same productivity of the 
sensitive crop grown in succession.

According to Procópio et al. (2007), previous cultivation of sunn hemp and jack bean legumes always led to increased productivity of bean crops compared with treatments without said previous cultivation, for all levels of soil contamination by trifloxysulfuron-sodium.

The best results for fresh and dry panicle mass of $P$. glaucum were obtained when $P$. glaucum was cultivated in soil previously remediated by $C$. juncea and $C$. ensiformis (Table 4). The contribution of these phytoremediator species to fresh and dry mass accumulation of $P$. glaucum panicles may be related to both the remedial potential of such species and the improvement of soil quality (FUMAGALLI et al., 2014). For example, the use of green manure species in pre-crop beans provides the highest grain yield, most notably bean-to-pig and crotalaria (GALLO et al., 2015).

The productivity or accumulation of mass in the panicles of indicator plants is one of the most important attributes to measure because it is the result of normal plant physiological development and indicates whether or not the environment imposes biotic or abiotic limitations. The potential of $C$. juncea and $C$. ensiformis to phytoremediate soils contaminated with up to $400 \mathrm{~g} \mathrm{ha}^{-1}$ sulfentrazone has already been confirmed (MADALÃO et al., 2013), and the results of the present study underline the capacity that these plant species have to decontaminate soil contaminated with this herbicide up to a dose of $800 \mathrm{~g} \mathrm{ha}^{-1}$ a.i. The results further show the contribution of the phytoremediation technique to increase the production of $P$. glaucum grains. In addition, the possibility that these phytoremediator species improved the physical, chemical and biological soil properties, resulting in increased production of $P$. glaucum grain, cannot be ruled out. It is known that green manure exerts important positive effects on the texture and structure of soil, minimizing the formation of compacted layers, adding carbon and nitrogen to the soil (WIESMEIER et al., 2015), and increasing faunal diversity, all of which contribute significantly to improving the physical, chemical and biological soil properties, and soil conservation (FERREIRA et al., 2012; ALMAGRO, MARTÍNEZ-MENA, 2014).

Table 4. Fresh and dry panicle mass of Pennisetum glaucum cultivated under different management systems of soil contaminated with the herbicide sulfentrazone, at 84 days after sowing.

\begin{tabular}{|c|c|c|c|c|}
\hline \multirow{3}{*}{$\operatorname{DOSE}\left(\mathrm{g} \mathrm{ha}^{-1}\right.$ a.i. $)$} & \multicolumn{3}{|c|}{ Fresh matter $^{(1)}$} & \multirow[b]{3}{*}{ Mean } \\
\hline & \multicolumn{3}{|c|}{ Management } & \\
\hline & Manual weeding & Crotalaria juncea & Canavalia ensiformis & \\
\hline 0 & 273.02 & 401.25 & 401.18 & 358.48 \\
\hline 200 & 209.72 & 251.58 & 334.43 & 265.24 \\
\hline 400 & 300.15 & 450.83 & 413.88 & 388.29 \\
\hline 800 & 235.52 & 328.76 & 439.92 & 334.73 \\
\hline Mean & $254.60 \mathrm{~b}$ & $358.10 \mathrm{a}$ & $397.35 \mathrm{a}$ & 336.69 \\
\hline CV (\%) & & 19.43 & & \\
\hline \multirow{2}{*}{$\operatorname{DOSE}\left(\mathrm{g} \mathrm{ha}^{-1}\right.$ a.i. $)$} & \multicolumn{3}{|c|}{ Dry matter $^{(1)}$} & \\
\hline & Manual weeding & Crotalaria juncea & Canavalia ensiformis & Mean \\
\hline 0 & 170.49 & 260.22 & 268.48 & 233.06 \\
\hline 200 & 177.00 & 150.77 & 223.41 & 183.73 \\
\hline 400 & 186.56 & 313.09 & 303.95 & 267.86 \\
\hline 800 & 143.56 & 217.67 & 296.90 & 219.38 \\
\hline Mean & $169.40 \mathrm{~b}$ & $235.43 \mathrm{a}$ & $273.19 \mathrm{a}$ & 226.01 \\
\hline $\mathrm{CV}(\%)$ & & 22.44 & & \\
\hline
\end{tabular}

${ }^{(1)}$ Means that are not followed by the same lower-case letter in rows differ based on Tukey's test at a significance level of 0.05 .

The results of this study indicate that phytoremediation as a technique for decontamination of areas where residues of the herbicide sulfentrazone persist, using the plant species $C$. ensiformis and $C$. juncea, may enable the initiation of pearl millet cultivation in these areas as much as 12 months earlier than would otherwise be possible. Under normal conditions, this herbicide can persist in soil for more than three years (BOVEY et al., 1982). This shortening of the time required to start cultivation was also observed for beans in areas where trifloxysulfuron-sodium phytoremediation was carried out; in this case, the susceptible species could be cultivated as much as six months earlier (PROCÓPIO et al., 2007). Other benefits, such as improved soil fertility and conservation, can also be obtained using phytoremediation in agricultural areas, as proposed in this study, notably in areas that involve intense soil usage with crop rotation programs (DAN et al., 2011).

\section{CONCLUSIONS}

Previous cultivation of $C$. ensiformis and $C$. juncea in the field promotes remediation of sulfentrazone-contaminated soil.

C. ensiformis is the most efficient species for the decontamination of soils containing the herbicide 
sulfentrazone under field conditions.

\section{ACKNOWLEDGMENTS}

To Conselho Nacional de Desenvolvimento Científico e Tecnológico and to Coordenação de Aperfeiçoamento de Pessoal de Nível Superior for the financial support and grants.

\section{REFERENCES}

ACCIOLY, A. M. A.; SIQUEIRA, J. O. Contaminação química e biorremediação do solo. In: NOVAIS, R. F.; ALVAREZ V. H.; SCHAEFER, C. E. G. R. (Ed.) Tópicos em Ciência do Solo. Viçosa: SBCS, 2000. v. 1, cap. 10, p. 299-352.

ALCÂNTARA, F. A. et al. Adubação verde na recuperação de fertilidade de um latossolo vermelhoescuro degradado. Pesquisa Agropecuária Brasileira, Brasília, v. 35, n. 2, p. 277-288, 2000.

ALMAGRO, M.; MARTÍNEZ-MENA, M. Litter decomposition rates of green manure as affected by soil erosion, transport and deposition processes, and the implications for the soil carbon balance of a rainfed olive grove under a dry Mediterranean climate. Agriculture, Ecosystems and Environment, Amsterdã, v. 196, n. 10, p. 167-177, 2014.

ANDERSON, T. A.; COATS, J. R. Screening rhizosphere soil samples for the ability to mineralize elevated concentrations of atrazine and metolachlor. Journal of Environmental Science and Health, Ames, v. 30, n. 4, p. 473-484, 1995.

ANDERSON, T. A.; KRUGER, E. L.; COATS, J. R. Enhanced degradation of a mixture of three herbicides in the rhizosphere of a herbicide-tolerant plant. Chemosphere, Oxford, v. 28, n. 8, p. 15511557, 1994.

ASSIS, R. L. et al. Fitorremediação de solo contaminado com o herbicida picloram por plantas de capim pé de galinha gigante. Revista Brasileira de Engenharia Agrícola e Ambiental, Campina Grande, v. 14, n. 11, p. 1131-1135, 2010.

BELO, A. F. et al. Fitorremediação de solo adubado com composto orgânico e contaminado com trifloxysulfuron-sodium. Planta Daninha, Viçosa, v. 25, n. 2, p. 251-258, 2007.

BELO, A. F. et al. Potencial de espécies vegetais na remediação de solo contaminado com sulfentrazone. Planta Daninha, Viçosa, v. 29, n. 4, p. 821-828,
2011.

BLANCO, F. M. G.; VELINI, E. D. Persistência do herbicida sulfentrazone em solo cultivado com soja e seu efeito em culturas sucedâneas. Planta Daninha, Viçosa, v. 23, n. 4, p. 693-700, 2005.

BOVEY, R. W.; MEYER, R. E.; HEIN JUNIOR, H. Soil persistence of tebuthiuron in the Claypan Resource Area of Texas. Weed Science, Champaign, v. 30, n. 2, p. 140-144, 1982

BUZINARO, T. N.; BARBOSA, J. C.; NAHAS, E. Atividade microbiana do solo em pomar de laranja em resposta ao cultivo de adubos verdes. Revista Brasileira de Fruticultura, Jaboticabal, v. 31, n. 2, p. 408-415, 2009.

CICEK, H. et al. Effects of grazing two green manure crop types in organic farming systems: $\mathrm{N}$ supply and productivity of following grain crops. Agriculture, Ecosystems and Environment, Amsterdã, v. 190, n. 6, p. 27-36, 2014.

DAN, H. A. et al. Atividade residual de herbicidas pré-emergentes aplicados na cultura da soja sobre o milheto cultivado em sucessão. Planta Daninha, Viçosa, v. 29, n. 2, p. 437-445, 2011.

FERRAÇO, M. Fitorremediação de solo contaminado com sulfentrazone em função da densidade populacional de Canavalia ensiformis e Crotalaria juncea. 2012. 68 f. Dissertação (Mestrado em Agricultura Tropical: Área de Concentração em Agricultura Tropical) Universidade Federal do Espírito Santo, São Mateus, 2012 .

FERREIRA, L. E.; SOUZA, E. P.; CHAVES, A. F. Adubação verde e seu efeito sobre os atributos do solo. Revista Verde, Mossoró, v. 7, n. 1, p. 33-38, 2012.

FOUCAULT, Y. et al. Green manure plants for remediation of soils polluted by metals and metalloids: Ecotoxicity and human bioavailability assessment. Chemosphere, Oxford, v. 93, n. 7, p. 1430-1435, 2013.

FUMAGALLI, P. et al. The rotation of white lupin (Lupinus albus L.) with metal-accumulating plant crops: A strategy to increase the benefits of soil phytoremediation. Journal of Environmental Management, Amsterdã, v. 145, n. 12, p. 35-42, 2014.

GALLO et al. Produtividade da cultura do feijoeiro em sucessão a adubos verdes, com adição de dejeto líquido de suínos. Revista Facultad de Agronomía La Plata, La Plata, v. 114, n. 3, p. 45-51, 2015. 
MADALÃO, J. C. et al. Susceptibilidade de espécies de plantas com potencial de fitorremediação do herbicida sulfentrazone. Revista Ceres, Viçosa, v. 60, n. 1, p. 111-121, 2013.

MADALÃO, J. C. et al. Uso de leguminosas na fitorremediação de solo contaminado com sulfentrazone. Pesquisa Agropecuária Tropical, Goiânia, v. 42, n. 4, p. 390-396, 2012.

MONQUERO, P. A. et al. Seleção de espécies de adubos verdes visando à fitorremediação de diclosulam. Planta Daninha, Viçosa, v. 31, n. 1, p. 127-135, 2013.

NASCIMENTO, A. F. et al. Risk of soil recontamination due to using Eleusine coracana and Panicum maximum straw after phytoremediation of picloram. International Journal of Phytoremediation, Boca Raton, v. 17, n. 4, p. 313$321,2015$.

PARAÍBA, L. C. et al. Evaluation of soil temperature effect on the herbicide leaching potential into groundwater in the brazilian cerrado. Chemosphere, Oxford, v. 53, n. 9, p. 1087-1095, 2003.

PERKOVICH, B. S. et al. Enhanced mineralization of $\left[{ }^{14} \mathrm{C}\right]$ atrazine in Kochia scoparia rhizospheric soil from a pesticide-contaminated site. Pesticide Science, London, v. 46, n. 4, p. 391-396, 1996.

PIRES, F. R. et al. Adubos verdes na fitorremediação de solos contaminados com o herbicida tebuthiuron. Revista Caatinga, Mossoró, v. 19, n. 1, p. 92-97, 2006.

PIRES, F. R. et al. Inferências sobre atividade rizosférica de espécies com potencial para fitorremediação do herbicida tebuthiuron. Revista Brasileira de Ciência do Solo, Viçosa, v. 29, n. 4, p. 627-634, 2005.

PROCÓPIO, S. O. et al. Development of bean plants in soil contaminated with trifloxysulfuron-sodium after Stizolobium aterrimum and Canavalia ensiformis cultivation. Planta Daninha, Viçosa, v. 25, n. 1, p. 87-96, 2007.

PROCÓPIO, S. O. et al. Potencial de espécies vegetais para a remediação do herbicida trifloxysulfuron-sodium. Planta Daninha, Viçosa, v. 23, n. 1, p. 9-16, 2005.

RIBEIRO, P. H. et al. Adubação verde, os estoques de carbono e nitrogênio e a qualidade da matéria orgânica do solo. Revista Verde, Mossoró, v. 6, n. 1, p. 43-50, 2011.
RODRIGUES, B. N.; ALMEIDA, F. S. Guia de herbicidas. 6. ed. Londrina, PR: Edição dos Autores, 2011. 697 p.

SANTOS, E. A.; CORREIA, N. M.; BOTELHO, R. G. Resíduos de herbicidas em corpos hídricos - Uma revisão. Revista Brasileira de Herbicidas, Londrina, v. 12, n. 2, p. 188-201, 2013a.

SANTOS, J. B. et al. Fitorremediação de áreas contaminadas por herbicidas residuais. In: SILVA, A. A.; SILVA, J. F. (Ed.). Tópicos em manejo de plantas daninhas. Viçosa: Universidade Federal de Viçosa, 2007. cap. 6, p. 249-278.

SANTOS, J. B. et al. Fitorremediação do herbicida trifloxysulfuron-sodium. Planta Daninha, Viçosa, v. 22 , n. 2 , p. $323-330,2004$

SANTOS, M. A. dos et al. Dinâmica de íons em solo salino-sódico sob fitorremediação com Atriplex nummularia e aplicação de gesso. Revista Brasileira de Engenharia Agrícola e Ambiental, Campina Grande, v. 17, n. 4, p. 397-404, 2013b.

TAVELLA, L. B. et al. O uso de agrotóxicos na agricultura e suas consequências toxicológicas e ambientais. Agropecuária Científica no SemiÁrido, Santa Cecília, v. 7, n. 2, p. 06-12, 2011.

WIESMEIER, M. et al. Remediation of degraded arable steppe soils in Moldova using vetch as green manure. Solid Earth, Göttingen, v. 6, n. 2, p. 609620,2015

WILSON, P. C.; WHITWELL, T.; KLAINE, S. J. Phytotoxicity, uptake, and distribuition of ${ }^{14} \mathrm{C}$ simazine in Acorus gramenius and Pontederia cordata. Weed Science, Lawrence, v. 48, n. 6, p. 701-709, 2000. 